○鈴木椧子、村本淳子、金澤卜シ子、國澤尚子

(東京女子医科大学看護短期大学)

阿部典子 (旭川医科大学) 、斎藤 真（愛知みずほ大学）

\title{
A Ergonomic Study of Mastering Blood Pressure Measurement.
}

- appraisal of the developed educational method

from perspectives of oblivion and recollection. -

OReiko Suzuki, Junko Muramoto, Toshiko Kanazawa, Naoko Kunisawa

(Tokyo Women's Medical College School of Nursing)

Noriko Abe (Asahikawa Medical College), Shin Saito (Aichi Mizuho College)

\section{1.はじめに}

筆者らは、㥀压测定技術について人間工学的側 面から実験研究し、初学者に効果的な教育方法を 考案してきた1) 2) 3)。

今回の研究は、考案した血压測定教育方法を教 示後、忘却の視点から検討した。教示 1 年後に再 び血圧測定を実施し、忘却の状態と記憶が再生さ れる経過から、考案した教育方法の有用性と問題 点を明らかにした。

\section{2. 実験方法}

被験者は二通りの教育方法で血圧測定を教示し た 1 年後の学生 8 名である。一つは手順による教 育方法（以下 $\Lambda$ 群と略す）ともう一つは考案した 教育方法 (以下B 群と略す) である。血圧测定を 連続して 6 回実施し、その状況をV T R に撮影し た。每回、血圧测定の動作と測定值の確認をべテ ラン看護婦が行った。測定終了後に 1 年間の血圧
測定経験の有無、記述による知識の確認、感想の 記述も行った。

血圧測定器具や血圧測定を受ける人の条件は前 回の実験と同様である。

\section{3. 実験結果}

分析は血圧測定行動を6つの動作に、動作数は 13動作に分類した。

(1)動作の所要時間

昨年の実験結果との比較では、A・B群ともに 全所要時間の平均はすべてで延長していた。しか し、B群の『マンシェットを巻く』は 6 回目で $10.4 \pm 5.7$ 秒と、昨年の実験 5 日目の結果と近接し ていた。そして、実験 2 日目以降、B群はA群よ りも早い時間でマンシェットが巻けていた。

『チェストピースを当てる』では、B群の 6 回

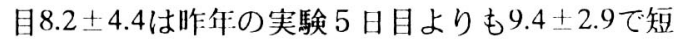
縮していた。

\section{表 1 血圧測定の平均所要時間}

\begin{tabular}{|c|c|c|c|c|c|c|}
\hline & & 全所要時間 & マンシェットを罕く & $F_{1}$ 자ピーースを当てる & 加圧 ·減圧する & その他 \\
\hline \multirow{7}{*}{ A 群 } & 阼年の籍験5日百 & $80.2+3.8$ & $11.4 \pm 2.7$ & $12.5+\quad 34$ & $49.2 \pm 6.1$ & $34 \pm 12$ \\
\hline & 1 回目 & $144.7 \pm 75.4$ & $19.5 \pm 12.6$ & $13.3 \pm 5.1$ & $94.9 \pm 75.4$ & $13.4 \pm 9.0$ \\
\hline & 2 回目 & $99.5 \pm 9.0$ & $12.2 \pm 5.7$ & $12.6 \pm 5.9$ & $45.6 \pm 15.3$ & $5.2 \pm 6.9$ \\
\hline & 3 回目 & $110.2 \pm 11.7$ & $16.8 \pm 6.7$ & $19.8 \pm 11.9$ & $58.8 \pm 10.3$ & $13.8 \pm 8.9$ \\
\hline & 4 回目 & $101.7 \pm 30.0$ & $17.0 \pm 7.6$ & $10.9 \pm 3.8$ & $62.5 \pm 16.7$ & $2.5 \pm 2.5$ \\
\hline & 5 回目 & $100.9 \pm 35.6$ & $31.7 \pm 36.9$ & $9.6 \pm 3.3$ & $49.6 \pm 21.0$ & $6.0 \pm 5.9$ \\
\hline & 6 回目 & $92.3 \pm 20.5$ & $13.9 \pm 5.2$ & $13.0 \pm 6.7$ & $52.7 \pm 19.6$ & $4.6 \pm 3.8$ \\
\hline \multirow{7}{*}{ B群 } & 昨年の实験5日目 & $72.6 \pm 127$ & $10.3 \pm 2.8$ & $9.4 \pm 29$ & $51,+122$ & 0 \\
\hline & 1 回目 & $101.2 \pm 20.6$ & $13.3 \pm 5.2$ & $14.8 \pm 6.0$ & $61.0 \pm 16.9$ & $3.8 \pm 7.2$ \\
\hline & 2 回目 & $108.0 \pm 27.4$ & $11.3 \pm 4.3$ & $14.3 \pm 8.5$ & $73.4 \pm 21.4$ & $2.7 \pm 2.4$ \\
\hline & 3 回目 & $88.3 \pm 23.5$ & $9.8 \pm 2.8$ & $11.1 \pm 7.1$ & $55.4 \pm 27.4$ & $2.8 \pm 1.9$ \\
\hline & 4 回目 & $120.2 \pm 30.4$ & $13.9 \pm 4.5$ & $22.8 \pm 27.1$ & $90.4 \pm 30.0$ & $3.2 \pm 4.5$ \\
\hline & 5 回目 & $94.4 \pm 19.7$ & $10.2 \pm 3.3$ & $8.6 \pm 3.5$ & $64.4 \pm 17.4$ & $6.0 \pm 10.8$ \\
\hline & 6 回目 & $114.7 \pm 39.4$ & $10.4 \pm 5.7$ & $8.2 \pm 4.4$ & $86.8 \pm 40.4$ & $2.6 \pm 3.0$ \\
\hline
\end{tabular}


『その他』の所要時間は実験全体を通してB群 の方が少なかった（表1参照）。

(2)動作数

その他の動作数の合計でも、B群では明らかに 動作数が少ない傾向にあった（図1参照）。

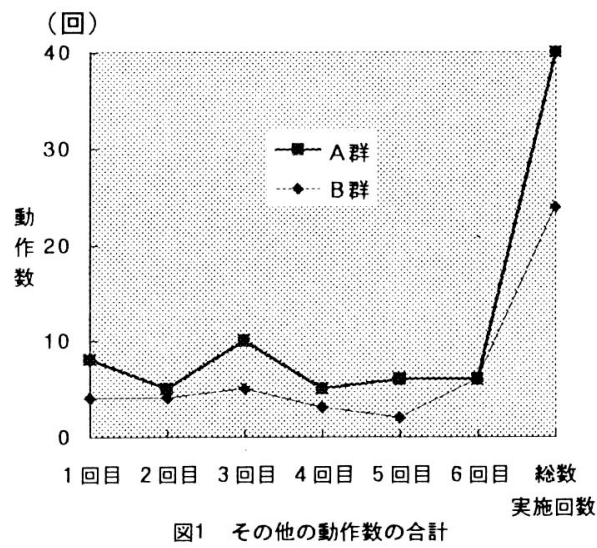

(3)測定の正確性

収縮期・抬張期血圧值の愦差はともにA 群の方 が少なかった。これは昨年の誤差比較とで逆転し た結果であった。

血圧测定動作の評価において、[マンシェット を巻く了が不適切之判断されたのべ回数はB 群で 3 回、A 群は16回であった。[チェストピースを 置く]でB群が不適切であったのべ回数は、1 回 のみであったのに対し A 群では 8 回であった。

[加圧・隇压の適切さ］は水銀を上げる高さと 減压のスピードの項目で、B 群の不適切回数が多 かった。

(4)記述内容

A 群は漠然とした感想にとどまっているが、B 群では自分の測定技術のどこに問題があったのか や測定の疑問な点を明確に表現していた。

\section{4. 考察}

今回の結果から、考案したIIII圧測定の教育方法 に対するいくつかの有用性が確認された。第 1 に 『マンシェットを巻く』の所要時間の短縮から、 マンシェットの巻き方は效率よく行えていること がわかる。これは教示 1 年後での忘却は少なく、 この動作が身につけられていたと考えられる。

第 2 に、客観的な評価からマンシェットの巻き 方が上腕動脈の走行に一致し、卷き具合も適切で あることは、正確な測定值を得るための確実な動 作が身についていると考えられる。血压测定に必 要な血管の走行や上腕とマンシェットの密着具合 に関して、1 年間のブランクがあっても記憶とし
て把持され実践できていたといえる。

第 3 に、上腕動脈の触知部位にチェストピース を速やかに置けたのは、解剖学的な知識に裹付け された理解ができたと考えられる。これは『千ェ ストピースを当てる』の所要時間が少ないことか らも同様に考えら机ることである。以上から、マ ンシェットを巻く練習を行うことは、動作を効率 よく正確に学ぶうえで有用であると考えられる。 これ以外に、『その他』の所要時間が少ないこと や感想の記述内容からは、考えながら行動して自 分の行動に対する評価が出来ていることもわか

る。こ机は、筆者らが考えている自らの行動を㓣 り出していく能力の基本が形成されてきていると もいえるだろう。

一方、考案した教育方法の問題点も確認され た。それは『加压・滅压する』動作の阶要時間の 延長、測定値の不正確さという結果から、『加 压・減圧する』動作の体得が不十分だと示唆され た。とくに、音を聞き分けるところでは知識とし て忘却していることや曖昧なままの理解があった のではないかと思われる。

教示後 1 年間の経過のなか、血圧測定の学習で 記憶として把持されているのは『マンシェットを 巻く』『チェストピースを当てる』である。『加 圧・滅压する』は他の行動から比較して忘却内容 が多く、検討の余地がある。

5.まとめ

初学者の血压測定行動において、教示後 1 年間 の間での忘却と記憶の再生過程に関して実験し た。考案した血圧測定教育方法による教示結果か らは次のことがわかった。

1)『マンシェットを巻く』動作の習得効果が高 い。

2)無䭾な動きが少ない傾向にある。

3)自らの行動を自己評価し、改善できる効果が 高い。

4)『加圧・減压する』動作の教育方法に工夫が 必要である。

<参考文献 $>$

1）鈴木玲子他：人間工学的侧面吕らの血正测定 技術教育の試案、東京女子医科大学看護短期大 学研究紀要、Vol.16、9-15、1995.

2）鈴木玲子他：人間工学的侧面からみた血压測 定技術の教育方法の開発、日本人間工学会第36 回大会講演集、164-165、1995.

3）鈴木玲子他：人間工学的侧面尔らの血圧測定 技術教育の研究 - 開発した教育方法の検証 - 、 東京女子医科大学看護短期大学研究紀要、 Vol..17、17-23、1995. 